\title{
Correction to: Distance learning in clinical medical education amid COVID-19 pandemic in Jordan: current situation, challenges, and perspectives
}

Mahmoud Al-Balas ${ }^{1 *}$, Hasan Ibrahim Al-Balas ${ }^{2}$, Hatim M. Jaber ${ }^{3}$, Khaled Obeidat ${ }^{4}$, Hamzeh Al-Balas ${ }^{5}$, Emad A. Aborajooh ${ }^{6}$, Raed Al-Taher ${ }^{7}$ and Bayan Al-Balas ${ }^{8}$

Correction to: BMC Med Educ 20, 341 (2020) https://doi.org/10.1186/s12909-020-02257-4

Following publication of the original article [1], the corresponding author Mahmoud Al-Balas would like to correct his affiliation. In this Correction, correct and incorrect versions are shown.

Incorrect: General and Breast Surgery, Department of General and Special Surgery, Faculty of Medicine, Hashemite University, Irbid-Amman Street, Al Husn, P.O.Box 3, Irbid 21510, Jordan

Correct: Department of General and Special Surgery, Faculty of Medicine, Hashemite University, Zarqa, Jordan.

The original article has been corrected.

\begin{abstract}
Author details
${ }^{1}$ Department of General and Special Surgery, Faculty of Medicine, Hashemite University, Zarqa, Jordan. ${ }^{2}$ Otorhinolaryngology, Faculty of Medicine, Yarmouk University, Irbid, Jordan. ${ }^{3}$ Community Medicine, Faculty of Medicine, Al-Balqa Applied University, Salt, Jordan. ${ }^{4}$ Department of General Surgery, Faculty of Medicine, Transplant and Hepatopancreaticobiliary Surgery, Jordan University of Science and Technology, Irbid, Jordan. ${ }^{5}$ Department of General and Special Surgery, Faculty of Medicine, General and Gastrointestinal Surgery, Hashemite University, Zarqa, Jordan. ${ }^{6}$ Department of General Surgery, Faculty of Medicine, General and Gastrointestinal Surgery, Mutah University, Mu'tah, Jordan. 'Pediatric Surgery, Department of General Surgery, Faculty of Medicine, Jordan University, Irbid, Jordan. ${ }^{8}$ Yarmouk University, Irbid, Jordan.
\end{abstract}

The original article can be found online at https://doi.org/10.1186/s12909020-02257-4.

* Correspondence: mahmoud_albalas@huedu.jo

'Department of General and Special Surgery, Faculty of Medicine, Hashemite University, Zarqa, Jordan

Full list of author information is available at the end of the article
Published online: 16 December 2020

\section{Reference}

1. Al-Balas, et al. BMC Med Educ. 2020;20:341. https://doi.org/10.1186/s12909020-02257-4.

(- The Author(s). 2020 Open Access This article is licensed under a Creative Commons Attribution 4.0 International License, which permits use, sharing, adaptation, distribution and reproduction in any medium or format, as long as you give appropriate credit to the original author(s) and the source, provide a link to the Creative Commons licence, and indicate if changes were made. The images or other third party material in this article are included in the article's Creative Commons licence, unless indicated otherwise in a credit line to the material. If material is not included in the article's Creative Commons licence and your intended use is not permitted by statutory regulation or exceeds the permitted use, you will need to obtain permission directly from the copyright holder. To view a copy of this licence, visit http://creativecommons.org/licenses/by/4.0/ The Creative Commons Public Domain Dedication waiver (http://creativecommons.org/publicdomain/zero/1.0/) applies to the data made available in this article, unless otherwise stated in a credit line to the data. 